DOI 10.14746/ssp.2021.4.5

\author{
Dawid Aristotelis FusIEK \\ Institute of European Democrats \\ ORCID ID: 0000-0002-7073-104X \\ Cecilia MARCONI \\ John Hopkins University \\ ORCID ID: 0000-0002-5097-6816
}

\title{
Trumpism and the European Far Right: An Analysis of Trumpism's Impact on the Post-2016 AfD, Lega Nord, and Fidesz
}

\begin{abstract}
The paper aims at investigating the relationship between Trumpism and the European far-right parties. The combination of shared ideological cores with the confrontation of similar "enemies" has resulted in the creation of an unprecedented relationship, wherein Trump takes the role of "international godfather" and inspiration for the European far right. To examine this relation, the paper focuses on references to Donald Trump and his policies and statements from 2016 to 2020 in the discourse of Alternative für Deutschland (AfD), Hungarian Civilian Alliance (Fidesz), and Lega Nord (Lega). The examination of the discourse of the three parties about security, immigration, foreign policy, and corruption shows that these parties have utilised Trumpism in three manners. Firstly, they have employed Trumpism to normalise certain pre-existing far-right ideologies and practices within their national and European context. Secondly, they have emulated Trump's discourse and policies to capitalise on his popularity and support their national endeavours. Thirdly, they have used Trump's fight and ideas to justify national measures, beliefs, criticism, or political goals. This paper thus aims to establish the leitmotifs governing the use of Trumpism by European far right to set the framework for future more critical analyses and a better understanding of this unprecedented relationship.
\end{abstract}

Key words: Trumpism, European far-right, populism, AfD, Fidesz, La Lega Nord

\section{Introduction}

D onald Trump has become a heroic figure for the fourth wave of the post-war far-right in Europe. Besides the charismatic and provocative persona of the 45th US President, the elements of his political ideology referred to as "Trumpism," such as nativism and the opposition to 
immigration and globalization, found popularity in the circles of global far-right. The return to a state-centric view of the world based on a Christian and conservative value and the need to hinder its alteration by media, economic elites, cultural Marxists, and the international liberal fora resonated with the European far-right. The latter has indeed been experiencing a resurgence after the three crises, namely the terrorist attacks of September 11, 2001 (and more recent terrorist hits in Europe), the Great Recession of 2008, and the European migrant crisis of 2015. Therefore, within this context, it is not surprising that the election of a similar-minded leader in the United States had a considerable impact on the European far-right.

Soon after Trump's victory, the European far-right sought to emulate the success of Trump's rhetoric and practices within their national and transnational context. The mirroring was facilitated by shared ideological themes and ideas on immigration, security, foreign policy, and corruption between Trumpism and the fourth wave of European far-right. An analysis into the discourse of European far-right parties shows that the election of Trump, his policies, and discourse were utilized in three manners: a) to normalize further certain pre-existing far-right ideologies and practices, which had been traditionally marginalized; b) to emulate similar practices and rhetoric within the national and transnational context; c) to justify national measures, beliefs, criticism, or political goals. The paper concentrates on the discourse of Alternative für Deutschland (AfD), Hungarian Civilian Alliance (Fidesz), and Lega Nord (Lega) and employs the qualitative method of process tracing to demonstrate the rational and social context behind these three patterns.

\subsection{Background}

The impact of the election of Donald Trump and Trumpism on the European right-wing parties is not unknown, as their unprecedented bond has attracted the interest of both academics and policymakers. Books like Pipa Norris and Ronald Ingehart's (2019) Cultural backlash: Trump, Brexit, and authoritarian populism, or papers as Michael Cox's (2017) "The Rise of Populism and the Crisis of Globalisation: Brexit, Trump, and Beyond" have examined Trumpism and European populist parties in the light of populist rhetoric and practices. Yet, most studies have ignored the impact of Trumpism on the European parties belonging to the far-right political spectrum. 
One of the first books to examine this interconnection was Cas Mudde's (2019) The Far-right Today, where the author establishes this ideological connection by focusing on the elements that constitute the modern far-right. According to the scholar, although Trump himself does not hold a populist radical right ideology, the discourse of his campaign is tautological to the core electorate of populist radical right parties in Europe. Indeed, this similarity has also allowed the transference of Trumpism in the European setting and its instrumentalization by the European far-right leaders. Apart from establishing the ideological bond, Mudde's work also highlighted two crucial points, namely: a) the emergence of the fourth wave of the post-war far-right in Europe; b) the establishment of the key ideological cores of the global far-right: immigration, security, corruption, and foreign policy.

\subsection{The Contemporary European Far-Right and Its Key Ideological} Cores

While traditionally the discussion on the far-right referred to far-right attitudes as individual pathologies, scholars have begun to study the farright in terms of ideology (Carter, 2018; Mudde, 2000). Ideologies constitute "all-encompassing sets of ideas" (Bale, 2017, p. 11), providing a normative framework for interpreting specific social and political issues. At the same time, they also function as a connecting link among divergent individuals by providing a basis for creating a common identity in political communities (Berman, 2001). Therefore, by positioning the far-right as an ideology, it is possible to distinguish its specific elements, characteristics, and leitmotifs and arrive at its definition based on the former.

In the last years, several definitions of far-right ideology have begun to appear in academia. One of the most interesting endeavors is Elisabeth Carter's latest contribution (2018), wherein the scholar attempts to combine the normative with the empirical dimension. Through an empirical analysis of a large selection of far-right organizations, she manages to come down to three essential features constituting a "minimal definition" of far-right ideology (Carter, 2018, p. 157). What characterizes Carter's work is that it managed to reconstruct the concept and set the base for similar future undertakings. Indeed, the year after Cas Mudde published the Far-Right Today, which applies Carter's finding on a European and global scale. 
In his book, Mudde attempts an ambitious endeavor, which describes the fourth wave of the post-war far-right. The scholar argues that since the beginning of the twenty-first century, and specifically due to the "three crises": terrorist attacks (from 9/11 onwards), the Great Recession of 2008, and the European migrant crisis, the far-right mainstream ideologies gained popularity. Furthermore, in line with Carter, Mudde offers an empirical analysis of the current wave of far-right groups and parties that seeks to locate its main ideological cores, elements, and characteristics. After an extensive empirical analysis of the global far-right, the scholar arrives at four political-issue clusters that are central to the ideology, rhetoric, and policies of the European and global far-right groups and parties: immigration, security, corruption, and foreign policy (Mudde, 2019, Chapter 2).

He also broadens the traditional perception of the far-right, excluding the conservative and liberal/libertarian parties and groups. Instead, he subsumes far-right by inducing two categories, the radical and the extreme far-right. While they both include right-wing groups outside the political mainstream or "the free democratic order," the latter refers to groups that adopt more drastic stances and ideologies threatening the constitutionality of the state. In other words, while the extreme right is revolutionary, the radical right is more reformist. In the former, Mudde also places rightwing populist parties that are pro-democracy and anti-liberal democracy. This decision is rather important as it allows the examination of many right-wing populist parties, such as AfD, Lega, and Fidesz, in the context of far-right ideology and based on the four aforesaid ideological cores.

Both Mudde and Carter's work are quintessential for understanding the modern far-right and the corresponding academic debate. As Anja Giudici (2020, p. 124) highlights, "by drawing the boundaries of the farright community based on ideology, it becomes possible to identify actors who have embodied this thought at different times and in different places." Whereas the common framework might neglect local programmatic and organizational variation, it is still especially advantageous as it offers a theoretical and empirical base to study a global and European phenomenon and show how they relate to each other and their context (Griffin, 2000; Mammone, 2015). Considering that, this research aims to contribute to the existing debate by applying the theoretical findings of Mudde's work while investigating the ideological and pragmatic impact that Trumpism had on the European far-right, specifically AfD, Fidesz, and Lega. 


\subsection{Methodology and Data}

The paper uses the research method of process tracing to examine the influence of Donald Trump on the European far-right. According to Andrew Benneth and Jeffrey T. Checkel, process tracing constitutes "the examination of intermediate steps in a process to make inferences about hypotheses on how that process took place and whether and how it generated the outcome of interest" (Bennett, Checkel, 2014, p. 6). This characterization closely follows George and Bennett's description of process tracing as a method that "attempts to identify the intervening causal process the causal chain and causal mechanism between an independent variable (or variables) and the outcome of the dependent variable" (George, Bennett, 2005, p. 206). In lieu of quantitative methods used to test larger populations and evidence, process tracing requires the careful examination of a single case or a few cases and provides evidence for singular causation. Therefore, within the context of the paper, it enables the establishment of the causal relations between Trump and Trumpism and the European far-right through the examination of the discourse and policies of three European far-right parties.

The paper thus focuses on the discourse of the far-right parties: Alternative für Deutschland (AfD), Hungarian Civilian Alliance (Fidesz), and Lega Nord (Lega), and especially references to Donald Trump and his policies and statements from 2015 to 2021 . While the paper acknowledges the limits of the selection of these parties (instead of some that could better fit a stereotypic perception of the far-right, e.g., the Nordic Resistance Movement in Sweden), the rationale behind their selection is two-fold. On the one hand, they have repeatedly exhibited and adopted the rhetoric, political stances, and policies identified within Mudde's four ideological cores (Mudde, 2019, Chapter 3). This leitmotif positions them on the far-right spectrum on a "global level," which allows the transfusion of Trumpism within the European context. On the other hand, these parties control a substantial number of seats in their national parliaments and the European Parliament. It is particularly relevant as their interactions with Trumpism can be analyzed in the realm of political communication and by considering their actual political agendas and initiatives.

To narrow the scope of analysis, the research concentrates on the official statements of the official representative of AfD, Fidesz, and Lega from 2016 to 2020 that can be found on web-based means. Besides that, the paper regards the representatives of politicians as the group of peo- 
ple who are being paid for their (political) activities. That implies that they convey their parties' positions, stances, and political goals, hence allowing the analysis of their discourse. Furthermore, the paper focuses on discourse because it helps examine the dialectic interaction between social contexts, the underlying ideology, and Trump (see, for example, Hart, Cap, 2014). This premise assumes that political discourse is not only a static public proposition, and words are not selected based on decorum criteria. Instead, politicians use words to affect political attitudes and opinions, manipulate public opinion, manufacture political consent, or legitimate political power. At the same time, the discourse itself functions as a manifestation of the intentions and beliefs of the politicians and the parties they represent. Therefore, the mix of discourse and process tracing allows the establishment of the rationale, the social context, and the discursive practices behind the European far-right's utilization of Trumpism. This undertaking is further facilitated by the shared ideology and four theme cores between the examined three parties and Trumpism.

\section{The Analysis}

The election of Donald Trump in 2016 took an almost symbolic meaning for AfD, Lega Nord, and Fidesz. In the aftermath of the "positive news," the then AfD's co-chairs, Frauke Petry and Jörg Meuthen, sent a congratulatory telegram announcing that the party would be a "natural ally at his side" and hailing this development as a "new era" - "a sea change for the entire world" (AfD, 2017a). The Hungarian Prime Minister, Viktor Orbán, did not lose the chance to express his satisfaction by describing the turn of events as "great news" and proof that democracy "is still alive" (Orbán, 2016). Matteo Salvini, the leader of the Lega Nord, hailed Trump's success and portrayed it as the "revenge of the people" and a "win for courage, pride, and labor and security issues against the banks, speculators, journalists, and pollsters" (ANSA, 2016). The other parties also shared the latter perception. For example, AfD deputy leader Beatrix von Storch wrote in a Facebook post that the "victory of Donald Trump is a signal that the people of the Western world want a clear political change" (Knight, 2016).

The three parties also perceived the election of a person with similar values, worldviews, and ideologies as a call for action on domestic and international levels. An excellent example is Salvini that interpreted 
the win as a "time to be more daring." Soon after the election, he cited Trump as the inspiration behind his upcoming rally in Florence on Saturday, November 12, 2016, against the Constitutional reform of Premier Matteo Renzi's government and described it as "[the]start of something, of a long march [...] [and a] beautiful day against everything" (ANSA, 2016). Therefore, it soon became apparent that this was not a single occurrence but an early manifestation of an ideological and pragmatic affiliation between the European far-right parties and Trumpism.

Since 2016, the three examined parties have not hesitated to use Trumpism to promote their interests and policies within the national and European context. This section shows that this utilization took three forms: the normalization of pre-existing far-right ideologies and rhetoric, the emulation of similar practices and discourse within the national and transnational setting, and the justification of political proposals or newly adopted policies. These leitmotifs become especially evident in the discourse of the three parties, where mentions to Trump seek to serve their political agendas and interest. Considering that AfD, Lega, and Fidesz belong to the European far-right, the analysis "orbits around" Mudde's four core themes, namely security, immigration, corruption, and foreign policy. These themes are shared by the three parties and provide a structure facilitating the better examination of the dynamics in the relationship between Trumpism and the European far-right.

\subsection{Security}

A closer look into the discourse of Donald Trump and the three examined parties reveals that security has played a crucial role in their policies, ideology, and worldview. The Trump presidency signalized a shift from a global soft power presence to a more state-oriented hard power approach (Olsen, 2019). Due to the underlying nativist and realist perception of the international system, Trump's discourse has focused mostly on the domestic domain and specifically on the security threats of jihadist terrorism and illegal migration. For instance, in his famous campaign speech on national security and terrorism (June 13), he condemned the anti-patriotic Hilary Clinton, blamed the immigrants for the crime in the US, and argued that "if we don't get tough [...] there will be nothing left" (Politico, 2016).

Similar rhetoric has also been present in the European far-right, which has been attributing the rise of crime to migration, globalization, leftist 
policies, and even conspiracies (BBC, 2020; Hestermann, Hoven, 2019). In this setting, the leaders and representatives of AfD, Lega, and Fidesz used Trumpism to normalize their previous focus on security and security concerns. Lega and Salvini have repeatedly praised Trump's proposals on security. In 2016, he characteristically stated that he would choose the "legality and security" of a Trump presidency over the "disastrous" policies of Angela Merkel and Barack Obama (Kirchgaessner, 2016). Similar leitmotifs are also present in the discourse of AfD that portrayed Trump's insistence on security either as a representation of their pre-existing concerns and proposals or to undermine the security policies of the leading German party, the Christian Democratic Union (CDU). For example, in 2018, the Deputy Federal spokesman Georg Pazderski went to the extent to say that "[Trump is] apparently more precisely informed about crime in Germany through his intelligence services than the German government" (AfD, 2018a). Ultimately, regarding the interconnection of Orbán and Trump, both have repeatedly expressed their appreciation and backed up each other security policies over their mutual meetings in the White House (Reynolds, 2019).

Trump and the European far-right have also been utilizing the concept of security as a proponent and excuse for the imposition of stricter legal and security measures on the national level. Before 2016, AfD, Fidesz, and Lega have repeatedly used the argument of security to attack their opposition (often dismissing their criticism as "Marxist") and to advocate for stricter law enforcement. Within this context, the three parties used Trumpism twofold: his "fights" and policies were emulated or used to justify similar policies and discourse. An excellent example is Donald Trump's quarrels clashes with numerous organizations and movements over the years of his presidency. For instance, in the aftermath of George Floyd's death, the former US President described the "riots" as incited by left-affiliated groups belonging to the "ANTIFA [...] Terrorist Organization" to portray them as security threats and members of the terroristic ANTIFA (Marquardt, 2021; Levine, 2021; Cummings, Phillips, 2020).

Facing similar groups in their countries, the three examined parties instrumentalized Trump's policies and rhetoric to challenge the internal criticism and social movements and attract more conservative voters. $\mathrm{AfD}$, which has been quite vocal about the terroristic nature of such leftist groups for many years, utilized the window of opportunity created by Trump to call for the ban on Antifa not only in Germany but also at the European level (European Parliament, 2020). Fidesz and Lega have also 
expressed similar stances that have collided with anti-fascist organizations (Reuters, 2017; Tondo, 2019). Characteristically, pro-Orbán media portrayed the 2020 Black Lives Matter (BLM) protestors as ANTIFA terrorists and the Hungarian BLM protests as incited by George Soros and his left-wing organizations, while Salvini has been vocal about his agreement with Trump's categorization of ANTIFA as a terrorist organization in his social media (Schlagwein, 2021).

Another interesting practice that the European far-right sought to emulate is Trump's combination of security arguments with issues belonging to the other three core themes. The far-right's broad definition of security allows the portrayal of numerous issues as security threats (for example, corruption and rise of crime), enabling the politicization and the adoption of extraordinary measures. Although this practice was already implemented in the past, Trump's presidency gave more ground to the European far-right for similar endeavors at the national level. Examples of the affiliation of the notion of security with matters related to corruption, foreign policy, and immigration are Orbán and Trump's effort to prohibit gender studies and present feminists as representative of the terrorist ANTIFA and corrupted liberal order, and Salvin's and AfD's identification of Muslims with terrorist (Scally, 2016). While it is difficult to establish the direct influence of Trump on these policies, this symbiosis becomes more evident through concrete cases in the remaining theme cores.

\subsection{Immigration}

Immigration has been a dominant theme in the discourse of both Donald Trump and the European far-right. Sharing a robust anti-immigration stance and policies, AfD, Fidesz, and Lega found a strong ally in Trump, who has posed the issue of illegal migration at the very core of his agenda (Hackman, 2020). The win of an anti-immigration US President combined with the series of terrorist attacks in Europe by Muslim extremists resulted in a new momentum for the European far-right (Allen, Knight-Finley, 2019). Given this window of opportunity, AfD, Fidesz, and Lega did not hesitate to use Trump's policies and discourse under the three leitmotifs. Still, due to pre-existing robust rhetoric and policies, Trump's influence mostly relied on normalization, justification, and less on emulation.

Firstly, the three far-right parties have sought to emulate Trump's anti-immigration policies within their national context. With a strong 
anti-immigration stance, AfD, Lega, and Fidesz have imitated Trump's policies and political agendas like increasing surveillance on the national borders or the induction of measures designed to disadvantage minorities (About Hungary, 2020; Sherer, 2018). An excellent example of the European far-right's imitation of Trump is the efforts to construct a fence at the borders to keep out the illegal migrants. While Orbán had already started to construct a fence to impede the arrival of Syrian refugees in 2015, he later decided to add another fence along Hungary's frontier with Serbia to "protect Europe from the flood of illegal migrants," inspired by Donald Trump similar endeavor to on the southern border of the States (Brady, 2017).

Salvini (as the Italian Minister of Internal Affairs) had also promised to build a wall on Italy's border with Slovenia to keep out migrants coming from the so-called Balkan route (Kington, 2019). He has also repeatedly cited Trump's anti-immigration policies, like the so-called "zerotolerance policy," as a form of inspiration in his speeches. For instance, in his 2019 interview with CNN, he clearly stated that he would be 'following' Trump's immigration policies (John, Ritchie, 2019). The AfD has also advocated for uncompromising border security and pointed out the need for "a fence" as a protective system on the border with Austria (Ametsbichler, 2017). Although in these cases, the impact of Trump was limited, they manifest the further mainstreaming of radical ideas and threat narratives within the national discourse.

The European far-right has also used Trump's anti-immigration discourse and rhetoric to justify new or pre-existing policies, political proposals, or opposition criticism. A good manifestation of this practice is provided by AfD, which due to its "minority status," has sought to appeal to more voters by imitating Trump's xenophobic rhetoric and challenging Angela Merkel's “open arms" migration policies. To draw the more conservative elements of German society, the party has attempted to instrumentalize Trump's criticism of Merkel's "insane" asylum policies and crime rates in Germany to show both the inefficiency of current migration policies and the need for a tougher approach (Oltermann, Connolly, 2016). Apart from that, the German far-right party has also instrumentalized the "Germany first" discourse to propose "Trumpist" measures and policies when it comes to border surveillance, migration, and asylum measures (Reuters, 2020). Similar to Trump, Lega and Fidesz have also been using threat narratives and "invasion" metaphors to demonize and present migration as a security threat to a nation's unity, identity, 
and culture (Khrebtan-Hörhager, 2018). While this rhetoric pre-existed the election of Donald Trump, it has since then experienced increased popularity. At the same time, Trump and his officials have shown direct approval and admiration for Lega and Fidesz in several instances, thus further normalizing their policies and rhetoric (Donadio, 2019; Borger, 2019). Interestingly, it is also the reference to Christian values and identity to justify their anti-immigration stances, especially directed against Muslims. While Orbán has described Trump as another Christian leader that "[does not] accept the hypocrisy of modern politics, which neglects the fact that Christianity is the most persecuted religion globally", Trump stated that he has "been great with respect to Christian communities" (The Guardian, 2019).

Thirdly, Lega, AfD, and Fidesz used Trump's positions on migration as a standing point to normalize their political agendas and far-right ideologies. This leitmotif has proved extremely dangerous and effective when combined with existing stances and contemporary phenomena such as the series of terrorist attacks in Europe after 2015. Trump's extensive use of xenophobic discourse and policies resulted in the further mainstreaming of anti-immigration legal and security measures and identification of local Muslim and, overall, migrant communities with terrorism. An excellent example of the latter is Islamism rhetoric at the global level. During his campaign, Trump used anti-terrorism and anti-Islam arguments against Hillary Clinton extensively, and within a week of becoming president, signed an executive order blocking Syrian refugees and banning citizens of seven predominantly Muslim countries from entering the United States (Beydoun, 2016).

In many European states, where animosity against Muslim migrants has been robust, this decision revamped and popularized these presuppositions and the perception that Islam does not belong in western societies (Shabi, 2016). This move was praised by Orbán, who repeatedly affirmed that his country "does not want Muslim invaders" and that "all terrorists are migrants" (Gherasim, 2016), while Salvini expressed that he would like to apply a similar measure in Italy (The Local, 2017). In Germany, AfD took a more drastic approach by adopting an anti-Muslim manifesto arguing that Islam "is not compatible with our legal system or with our culture" (Knight, 2016). Therefore, there is no denying that Trump's Islamophobic rhetoric reignited the anti-Islam stances of the three parties and the rhetoric of clashes of civilization, where Trump and the European far-right function as the last frontier. 


\subsection{Corruption}

Corruption has been a further key theme in the discourse of the European far-right and Donald Trump. What differentiates corruption from the other themes is its strong populist nature, which relies on the "us-vsthem" discourse (Mudde, 2019). The European far-right parties have thus used the accusation of corruption to impair the criticism of the corrupted elites, including the political opposition and left-wing parties ("them"), while building a stronger sense of the in-group based on shared values, ideas, and leadership ("us"). This populist practice had already figured in the speeches and statements of the three examined parties before the election of Trump. However, the success of a prominent populist and fighter of corruption in the US resulted in the surfacing of anti-corruption discourse in line with the three patterns.

Following Trump's win, AfD, Fidesz, and Lega have sought to take advantage of the mainstreaming of anti-corruption discourse. For AfD, the similar-minded Trump and his collisions with corrupted political elites constitute both an example of a nativist leader and the manifestation of their political goals (AfD, 2018b; AfD, 2016). A great example is AfD's use of Trump's continuous criticism of Germany and Chancellor Angela Merkel to support its pre-existing nativist agenda and anti-immigration ideologies, such as Trump's 2018 tweets presenting Germany as a crime-ridden and immigrant state (Colvin, Miller, 2018; Oltermann, Connolly, 2016). AfD has also used the anti-elite discourse alto dismiss internal criticism and attacks against the party by portraying the accusers as the representative of the corrupted elites. The party has employed this practice to challenge the elite-driven and false narrative of the popular media in Germany that have portrayed in a negative spotlight the party and Trump (AfD, 2017b).

Similar patterns are also present in Fidesz and Lega, which have found in Trump an important ally in the fight against "liberal imperialism" (McLaughlin, 2019). Orbán has instrumentalized Trump's Christian identity and anti-LGBTQ attacks to support his domestic constitutional amendments mandating Christian gender roles and marginalizing "corrupted" globalized ideologies (Tjalve, 2020). For instance, both Trump and Orbán have adopted or made efforts to prohibit gender studies and alter gender definition in their states (Apperly, 2019). Furthermore, Trump's reference to George Soros, a Hungarian philanthropist, representing the corrupted global elites normalized Orbán's policies and populist internal 
discourse (Vogel, Shane, Kingley, 2018). When it comes to Salvini, he has not been hesitant of employing Trump's nativist and anti-elite discourse to normalize his fight against corrupted non-governmental organizations like in the case of the 2018 port closure targeting migrant vessels (BBC, 2018).

Another interesting leitmotif is Trumpism as a justification for adopting more authoritarian measures. Apart from serving as a normalizing factor of pre-existing ideologies and criticism, Trump's mistreatment by the global elites becomes a reference point for the representatives of the three parties. This practice is causally linked to the prevalent strongmen and machismo policies (strong and aggressive masculine pride) employed by the three parties that aim to attract more conservative voters while presenting themselves as the last barrier against "cultural Marxism" and globalization (Lendval, 2017). An interesting example, already mentioned in this paper, is the identification of internal protests and left-wing organizations with the BLM riots to justify the previous measures against leftist organizations or the perception as internal security threats. Other examples of this practice are the responses of the three parties to Trump's loss in the 2020 election and his 2020 Twitter ban. Both events were described by Fidesz, AfD, and Lega as attempts to "shut down" the will of the people, such as the accusations of corruption and electoral fraud and manifestations of the dangers of "Marxist" political ideas (Dettmer, 2020; Al Jazeera, 2021). Moreover, Trump's marginalization has also been utilized to create a martyr perception of the European far-right and validate a global agenda's pre-existing "scenarios." This seemingly harmless phenomenon has led to the spread of numerous conspiracy theories featuring Trump at its epicenter related to the European far-right, like the connection of QAnon and AfD (Bennhold, 2020).

The three parties have not hesitated to imitate Trump's "us-vs-them" narrative on the national and European levels. Interestingly, this emulation was mostly utilized to challenge transnational agendas expressed by economic and political elites. An excellent example of this practice is the reference to or adoption of Trump's "America First" type of slogans by the three parties to support their nativist arguments and opposition to globalization supported by the political elites in Brussels (Bennhold, 2020b). This leitmotif was also present in the fight against the popular media, where the three parties have invested further in social media to offer the truth to the people without the alterations of media. An excellent example is Salvini, who has imitated Trump's discourse 
to underline how the newspapers that disapprove of his work represent the elite while portraying himself as making real efforts to improve the country's conditions (Arfini, 2019). In a similar line with Lega, AfD hired in 2017 the same ad agency that worked on Trump's campaign to manage its political campaign on the popular media (Petzinger, 2017). Due to the longstanding use of populist anti-elite discourse, Orbán's emulation of Trump's discourses resided only on attacks against Soros and the European Union.

\subsection{Foreign Policy}

Donald Trump's approach to foreign policy has hugely impacted the European far-right. Even before his election, parties like AfD, Lega, and Fidesz had supported a state-centric worldview in the aftermath of the 2015 European migrant crisis and several terrorist attacks on European grounds. Furthermore, they had also collided with the European Union regarding integration, sovereignty, and immigration issues. While the third wave of far-right proposed the dissolution of the whole undertaking, the contemporary European far-right parties advocate for a looser union that does not intervene in the national matters of its Member States (Down, Han, 2020). These sentiments were specially reinforced following the 2016 Brexit referendum. Considering this political background, Trumpism found fertile ground in an already highly divided continent. Trump's nativism caused an unprecedented revitalization of European nativist tendencies (Roth, 2019). On the one hand, the European far-right mirrored and used Trump's "our-country-first" to capitalize on patriotic feelings, anti-immigration sentiments at the national level. On the other hand, they also employed Trumpism to further challenge transnational institutions and justify their pre-existing or new policies. Still, both endeavors manifested the three patterns of emulation, normalization, and justification.

AfD, Lega, and Fidesz have emulated Trump's nativist policies within the national and European context while praising his focus on national interest. The research has already mentioned a few manifestations of this practice that have been combined with one of the other three themes. For example, the construction of the walls on the borders or the fight against corrupted elites were supported by strong Trump-inspired nativist arguments. However, the best example of the three parties mirroring 
Trumpism is the adoption of almost tautological nativist campaign slogans and political agendas by AfD, Lega, and Fidesz. Concretely, motivated by Trump's success, Italy's Matteo Salvini presented a "Prima gli Italiani" (Italians first) slogan in 2016, which encompassed a new migration agenda for his country, social reforms to disadvantage minorities, and mirrors Trump's trade scheme. A similar discourse was used by AfD members, which attempted to profit from the anti-immigration sentiments caused by the European migrant crisis. In 2017, Alexander Gauland, AfD vice-chairman, affirmed that the political agenda of Trump explicitly inspired them: "In the US, they have America First, so we can have Germany First" (Bennhold, 2020). On the same note, Orbán has also taken up Trump's discourse to support his already populist and nativist agenda: "we have enthusiastically applauded the President of the United States for thinking precisely as we do when he says, 'America First.' We say the same: Hungary first, and then everyone else" (Orbán, 2017).

Secondly, Trump's nativism normalized and popularized the already present Euroscepticism and state-centric ideologies of the European farright. AfD, Lega, and Fidesz seek to restore the EU to a community of independent member states because they believe that the integration process has overreached itself and the Union has turned into a hostile and remote bureaucracy (Wildangel, 2018). Trump's criticism of the EU's global modus operandi, handling of issues of security and immigration, or even identification with the corrupted elites served as validation and motivation for further action. For example, at the summit of the political group in the European Parliament, Europe of Nations and Freedom (ENF), AfD and Lega describe Trump's win as "the start of a patriotic spring in Europe" (Brady, 2017). Indeed, following the dissolution of ENF, Lega, AfD, and other far-right European parties launched its successor, the nationalist, right-wing, and Eurosceptic, "Identity and Democracy" (ID) in 2019. It is also important to point out the influence of President Trump's former chief strategist, Steve Bannon, in creating the party. Soon after its establishment, the party's connection with Donald Trump became apparent through repeated statements of support on social media and in the European Parliament (ID, 2020). In fact, in September 2020, a few of ID's Members proposed within the European Parliament a motion to award the Nobel Peace Prize to Donald Trump (EP, 2020). In their discourse, the party representatives have also repeatedly referred to Trump, calling for the gradual "dismantlement" of EU political "constraints," yet they do not seem to have or promote any other alternative. When it comes to Orbán, 
following Fidesz's withdrawal from European People's Party in March 2021, he announced a perspective of a new right-wing alliance with similarly minded leaders as Salvini (Zalan, 2021).

Thirdly, the three parties utilized Trump's nativist discourse to justify their protectionist and nativist measures and policies, mostly at the national level. Facing internal and external criticism, Trump became an important ally for AfD, Lega, and Fidesz in their efforts to retain their sovereignty from the EU. It is visible in Orbán's 2016 statementing, where he describes Donald Trump as "better for Europe" and refers to his antiimmigration and counterterrorism policies to criticize the "bureaucrats in Brussels" (Gorondi, 2016). Similar leitmotifs are present in the following four years. For example, in 2020, Orbán declared his support for Trump's re-election as he is a key ally in a battle for "illiberal democracy" against "loopy liberals" in the European Union who support mass immigration (Waterfield, 2020). Another interesting case is the 2018 decision of the Trump administration to impose punitive tariffs on aluminum and steel imports on European exports. While the European official heavily condemned this decision, the European far-right perceived it as an example of a leader defending the state's interests. It also utilized this occurrence to justify its previous arguments against globalization and excessive regulation stemming from transnational institutions such as the European Union. AfD's Kay Gottschalk has repeatedly praised Trump's move that showed the hypocritical nature of the EU: it "rises to be the guardian of free world trade" but simultaneously sustains the "perverse consequences of globalization" based on European taxpayers. Moreover, he prompts the EU to learn from Trump and leave financial issues to sovereign states (ibid.). A similar discourse was also adopted by Salvini that promised to the Italians that he would become their Trump and impose economic tariffs to protect the Italian interests against Brussels bureaucracy (Koukakis, 2018; Follain, Albanese, 2019).

\section{Conclusions}

This paper has investigated the influence of Trumpism, Trump's political movement, on the European far-right. The election of a similarminded politician in the United States was perceived as a window of opportunity for the European far-right parties for further action on the national and international level. The success of Trumpism within the 
US also inspired the far-right to imitate or "transfer" similar endeavors within their national context. Indeed, Trumpism's core ideological elements found fertile ground in Europe, where the fourth wave of European far-right had gained momentum after the terrorist attacks of September 11, 2001 (and more recent terrorist hits in Europe), the Great Recession of 2008, and the European migrant crisis of 2015. As Cas Mudde (2019) highlights, this convergence has been possible due to both movements' shared themes and ideological cores. To portray the European far-right's utilization of Trumpism, the research has focused on references to Donald Trump and his policies and statements from 2016 to 2020 in the discourse of AfD, Fidesz, and Lega. By employing the method of process tracing and focusing on the four themes of security, immigration, foreign policy, and corruption, the research shows that they have utilized Trumpism in three manners.

Firstly, AfD, Lega, and Fidesz have used Trumpism as a standing point to normalize certain pre-existing far-right ideologies and practices within their national context, thus leading to their intensification and growing popularity. This leitmotif has proved to be extremely dangerous and efficient when combined with existing stances and contemporary negative phenomena, such as terrorist attacks and migration problems. An excellent example is Trump's "us-vs-them" narrative utilized in issues of immigration and corruption, which led to the further mainstreaming of pre-existing populist practices and discourse, such as the anti-elite and globalization discourse, or strong anti-Islamist rhetoric of the European far-right. Secondly, they have imitated and attempted to adopt Trump's discourse and policies domestically and internationally. Excellent examples are the emulation of the "our-country-first" narrative and Trump's nativist policies within the national and European context. Other instances are also the three parties' imitation of Trump's anti-elite discourse to undermine the criticism of media and political opposition or their use of security as a proponent for adopting more drastic measures. Thirdly, they have used Trump's fight and ideas to justify national measures, beliefs, criticism, or political goals. This pattern was demonstrated by the three parties' efforts to ban ANTIFA and their response to Trump's loss in the 2020 election and his 2020 Twitter ban. All these events were described as attempts to "shut down" the will of the people, the accusations of corruption and electoral fraud, and manifestations of the dangerous "Marxist" ideas.

Presently, after Trump's loss in the 2020 US elections, the state of Trumpism is as unclear as the scenarios regarding how its relationship 
with the European far-right might subsequentially evolve. While initially the parties had been enthusiastically endorsing his candidacy, challenging the credibility of election results, invocating frauds and conspiracy theories, there are now starting to distance themselves from Trump. Following the events of Capitol Hill, they have reluctantly condemned Trump's supporters for their violent insurrection against the US Congress. This behavior is a great manifestation of the flexibility and independence of the European far-right from Trumpism. Contemporarily, the pandemic of COVID-19 is reshaping their agendas and has had mixed effects on their electoral support: while it might prove easier for them to criticize the ruling elite, the latest polls indicate that they are experiencing a decrease in popularity. However, it is safe to assume that the European far-right will continue to play an important role in the years to come as the political and ideological conditions that facilitated the acceptance of Trumpism are still there. It is difficult to assess whether there is a place for Trumpism in the future of the European far-right as Trump's defeat did not only deconstruct his "success story" but also dismissed his authority and power. Still, the growing popularity of Trump-inspired conspiracy theories shows that while the era of Trumpism has ended in the populist radical right, this might not be the case in the extreme far-right movements in Europe.

\section{Bibliography}

Alternative für Deutschland (AfD) (2018a), Georg Pazderski: Trump Kennt Kriminalität In Deutschland Wohl Besser Als Merkel - Alternative Für Deutschland, "Alternative Für Deutschland", accessed February 2021, https://www.afd.de/ georg-pazderski-trump-kennt-kriminalitaet-in-deutschland-wohl-besser-alsmerkel/.

Alternative für Deutschland (AfD) (2018b), Georg Pazderski: Deutschland Täte Gut Daran, Sich Unvoreingenommen Mit Trump Und Seiner Agenda Zu Befassen - Alternative Für Deutschland, "Alternative Für Deutschland", accessed February 2021, https://www.afd.de/georg-pazderski-deutschland-taete-gutdaran-sich-unvoreingenommen-mit-donald-trump-zu-befassen/.

Alternative für Deutschland (AfD) (2017a), Glückwunschtelegramm Der Afd And Donald Trump - Alternative Für Deutschland, 2017, “Alternative Für Deutschland", accessed February 2021, https://www.afd.de/glueckwunschtelegrammder-afd-an-donald-trump/.

Alternative für Deutschland (AfD) (2017b), Gauland: Frau Merkel Ist Die Schoßpuppe Von Gabriel - Alternative Für Deutschland, "Alternative Für Deutschland", accessed February 2021, https:/www.afd.de/gauland-frau-merkel-istdie-schosspuppe-von-gabriel/. 
Alternative für Deutschland (AfD) (2019), Afd Demands Radical EU Reforms To Avoid Germany's 'Dexit', DW, 13.01.2019, DW.COM, accessed February 2021, https://www.dw.com/en/afd-demands-radical-eu-reforms-to-avoid-germanys-dexit/a-47066983.

ANSA (2016), Salvini hails Trump election as 'revenge of the people', ANSA.com, accessed February 2021, https://www.ansa.it/english/news/2016/11/09/salvini-hails-trump-election-as-revenge-of-the-people-3_e5b17b7b-819f-481c808c-92fe742baa81.html.

Apperly E. (2019), Why Europe's Far-right Is Targeting Gender Studies, "The Atlantic", accessed February 2021, https:/www.theatlantic.com/international/ archive/2019/06/europe-far-right-target-gender-studies/591208/.

Arfini L. (2017), Salvini and Di Maio harshly attack Italian journalists on social media - but in different ways - The New Federalist, "The New Federalist", accessed February 2021, https://www.thenewfederalist.eu/salvini-and-di-maioharshly-attack-italian-journalists-on-social-media- $\%$ E2\%88\%92?lang=fr.

Bale J. M., Eatwell R. et al. (2017), The Darkest Sides of Politics, I: Postwar Fascism, Covert Operations, and Terrorism, Routledge.

BBC (2018), Migrant Crisis: Italy Minister Salvini Closes Ports To NGO Boats, accessed February 2021, https://www.bbc.com/news/world-europe-44668062.

BBC (2020), Italy's Salvini To Face New Trial Over Migrant Ship Blockade, "BBC News", accessed February 2021, https://www.bbc.com/news/world-europe-53592852.

Beeman R. D. (2018), What are the three characteristics of Trumpism? A Discourse Analysis of Trump's Four Major Campaign Speeches, "Political Analysis", 19(1), 2.

Beinart P. (2020), Trump Has A Different Definition Of 'Corruption', “The Atlantic”, accessed February 2021, https://www.theatlantic.com/ideas/archive/2020/08/ trump-has-different-definition-corruption/615802/.

Bennett A., Checkel J. (eds.) (2014), Process Tracing: From Metaphor to Analytic Tool (Strategies for Social Inquiry), Cambridge University Press, doi: 10.1017/CBO9781139858472.

Bennett A., Alexander L. G. (2005), Case studies and theory development in the social sciences, MIT Press.

Bennhold K. (2020), Qanon Is Thriving In Germany. The Extreme Right Is Delighted, Nytimes.com, accessed February 2021, https://www.nytimes. com/2020/10/11/world/europe/qanon-is-thriving-in-germany-the-extremeright-is-delighted.html.

Beydoun K. A. (2016), Islamophobia: Toward a Legal Definition and Framework, "Columbia Law Review Online" 108, available at SSRN: https://ssrn.com/ abstract $=2933156$.

Borger J. (2019), Trump Lauds Hungary's Nationalist PM Orbán For 'Tremendous Job', "The Guardian", accessed February 2021, https://www.theguardian. 
com/us-news/2019/may/13/trump-latest-viktor-Orbán-hungary-prime-minister-white-house.

Brady K. (2017), EU's Right-Wing ENF Faction Unites To Fight For 'Patriotism, Sovereignty And Identity', DW, 21.01.2017, DW.COM, accessed February 2021, https:/www.dw.com/en/eus-right-wing-enf-faction-unites-to-fight-forpatriotism-sovereignty-and-identity/a-37224232.

Carter E. (2018), Right-wing extremism/radicalism: reconstructing the concept, "Journal of Political Ideologies", 23:2, pp. 157-182, DOI: 10.1080/13569317.2018.1451227.

Colvin J., Zeke M. (2018), Trump Stands By “Culture” Criticism Of European Immigration, "Denverpost.Com, accessed February 2021, https://www.denverpost. com/2018/07/13/trump-criticism-european-immigration/.

Conley R. S. (2020), Donald Trump and American Populism. New Perspectives on the American Presidency, Edinburgh University Press, Edinburgh.

Cox M. (2017), The Rise of Populism and the Crisis of Globalisation: Brexit, Trump and Beyond, "Irish Studies in International Affairs" 28, pp. 9-17, https://doiorg.proxy.library.uu.nl/10.3318/isia.2017.28.12.

Cummings W., Philips K. (2020), Trump Says He'll Designate Antifa A Terror Organization, Blames Group For Violence At George Floyd Protests, Eu.Usatoday.Com. accessed February 2021, https:/eu.usatoday.com/story/ news/politics/2020/05/31/george-floyd-protests-trump-antifa-terrorist-organization/5299766002/.

Dettmer J. (2020), US Election Results Dismay Trump's Populist Allies In Europe, "Voice Of America", accessed February 2021, https://www.voanews.com/europe/us-election-results-dismay-trumps-populist-allies-europe.

Donadio R. (2019), The Italian Donald Trump Visits Washington, "The Atlantic", accessed February 2021, https://www.theatlantic.com/international/archive/2019/06/salvini-us-visit/591874/.

Down I., Kyung Joon H. (2020), Far-right Parties And 'Europe': Societal Polarization and The Limits Of EU Issue Contestation, "Journal of European Integration”, 43:1, pp. 65-81, DOI: 10.1080/07036337.2020.1728263.

European Parliament (2020), Classification of Antifa As A Terrorist Group, Europarl. Europa.Eu, accessed February 2021, https://www.europarl.europa.eu/doceo/ document/E-9-2020-003936_EN.html.

Follain J., Albanese C. (2019), Salvini Tells Italians He Can Be Their Very Own Donald Trump, Bloomberg.com, retrieved February 20, 2021, https://www. bloomberg.com/news/articles/2019-05-16/salvini-tells-italians-he-can-betheir-very-own-donald-trump.

Gherasim C. (2016), Eastern Europe Wakes Up With Trump Hangover, accessed February 19, 2021, "Euobserver", https://euobserver.com/political/150698.

Giudici A. (2021), Seeds of authoritarian opposition: Far-right education politics in post-war Europe, "European Educational Research Journal", 20(2), pp. 121-142, DOI: 10.1177/1474904120947893. 
Gorondi P. (2016), Hungary's Orban says Donald Trump better for Europe, Timesofisrael.com, accessed February 2021, https:/www.timesofisrael.com/hungarysorban-says-donald-trump-better-for-europe/.

Griffin R. (2000), Interregnum or endgame? The radical right in the 'post-fascist' era, "Journal of Political Ideologies", 5(2), pp. 163-178, DOI: 10.1080/713682938.

Hackman M. (2020), Where Trump And Biden Stand On Immigration, Border Wall And ICE, WSJ, accessed February 2021, https://www.wsj.com/articles/where-trump-and-biden-stand-on-immigration-border-wall-and-ice11600335000 ? mod=e2fb\&fbclid=IwAR1i5eppcT3obvruhQRTTnDYuW1ep uAHSsNUTANOet_JPSNQWaFA1uCItAc.

Hestermann T., Hoven E. (2019), Kriminalität In Deutschland Im Spiegel Von Pressemitteilungen Der Alternative Für Deutschland (Afd) - Kripoz, Kripoz.De, https://kripoz.de/2019/05/29/kriminalitaet-in-deutschland-im-spiegel-vonpressemitteilungen-der-alternative-fuer-deutschland-afd/.

ID (2020), Identity and Democracy, Twitter.com, https://twitter.com/IDParty_/status/1352569596755238914.

John T., Ritchie H. (2019), Salvini Has Been 'Following' Trump's Immigration Policies, But He Will Not Separate Children, CNN, accessed February 2021, https:/edition.cnn.com/2019/06/14/europe/salvini-immigration-amanpour-intl/ index.html.

Khrebtan-Hörhager J. (2018), Inflammatory Rhetoric of Othering in Times of Humanitarian Crises, National Communication Association, accessed February 2021, https://www.natcom.org/communication-currents/inflammatory-rhetoric-othering-times-humanitarian-crises.

Kirchgaessner S. (2016), Donald Trump Gets My Backing, Says Italy's Matteo Salvini, "The Guardian", accessed February 2021, https://www.theguardian. com/world/2016/apr/26/donald-trump-gets-my-backing-says-italys-matteosalvini.

Knight B. (2016), Merkel congratulates Trump as politicians express shock, DW.com, accessed February 2021, https://www.dw.com/en/merkel-congratulatestrump-as-politicians-express-shock/a-36318866.

Koukakis N. (2018), Not all Europeans hate Trump's tariff policy - Italy's far-right PM candidate loves it, CNBC, accessed February 2021, https://www.cnbc. com/2018/03/02/italys-far-right-populist-pm-candidate-loves-trumps-tariffpolicy.html.

Lendval P. (2017), Orbaěn: Europe's New Strongman | College Of Europe, Coleurope.eu, accessed February 2021, https://www.coleurope.eu/orban-europesnew-strongman.

Mammone A. (2015), Transnational neofascism in France and Italy, Cambridge University Press.

McLaughlin D. (2019), Hungary's Orbán Derides' Liberal Imperialism' After New EU Court Defeat, "The Irish Times", accessed February 2021, https://www. 
irishtimes.com/news/world/europe/hungary-s-orban-derides-liberal-imperialism-after-new-eu-court-defeat-1.4283498.

Mudde C., Kaltwasser C. R. (2013), Political leadership and populism, in: The Oxford Handbook of Political Leadership, DOI: 0.1093/oxfordhb/ 9780199653881.013.016.

Mudde Cas. (2019), The far-right today, John Wiley \& Sons.

Norris P., Inglehart R. (2019), Cultural backlash: Trump, Brexit, and authoritarian populism, Cambridge University Press, DOI: https://doi. org/10.1017/9781108595841.

Olsen G. R. (2019), Donald Trump and "America first": the road ahead is open, "International Politics”, pp. 1-19.

Oltermann P., Connolly K. (2016), Angela Merkel Admits Mistakes Over Asylum Seekers After Disastrous Election, "The Guardian", accessed February 19, 2021, https://www.theguardian.com/world/2016/sep/19/angela-merkel-admits-mistakes-asylum-seekers-election.

Orbán V. (2017), Abouthungary.hu, accessed February 19, 2021, http://abouthungary. $\mathrm{hu} /$ speeches-and-remarks/prime-minister-viktor-orbans-speech-at-the-closing-event-for-the-national-consultation/.

Orbán V. (2021), Facebook.com, accessed February 2021, https://www.facebook. com/Orbánviktor/photos/a.311926051092/10154577434131093/.

Petzinger J. (2017), Germany'S Far-Right Party Hired an Ad Agency That Worked On The Trump Campaign, Quartz, https://qz.com/1067764/germanys-farright-afd-party-hires-harris-media-an-ad-agency-that-worked-for-the-trumpcampaign/.

Politico (2016), Transcript: Donald Trump's National Security Speech, accessed February 2021, https://www.politico.com/story/2016/06/transcript-donaldtrump-national-security-speech-224273.

Reuters (2017), Ruling Fidesz Party Wants Soros-Funded NGOs "Swept Out” Of Hungary, U.S., accessed February 2021, https://www.reuters.com/article/ukhungary-fidesz-soros-idUKKBN14U2O3? edition-redirect=uk.

Reuters (2020), Hungary Government Proposes Constitutional Amendment Mandating Christian Gender Roles, U.S., accessed February 2021, https://www.reuters.com/article/us-hungary-lgbt-constitution-idUSKBN27Q34Z.

Reynolds J. (2019), Matteo Salvini: Can Italy's Populist Leader Return To Power?, BBC News, accessed February 2021, https://www.bbc.com/news/world-europe-44921974.

Roth S. (2019), Progressive And Right-Wing Counter-Movements Are Rising In The Age Of Brexit, LSE BREXIT, https://blogs.lse.ac.uk/brexit/2019/02/28/counter-movements-to-brexit-are-on-the-rise/.

Scally Derek (2016), Germany's populist AfD steps up anti-Muslim policies, "The Irish Times", accessed February 2021, https://www.irishtimes.com/news/world/europe/germany-s-populist-afd-steps-up-anti-muslim-policies-1.2614789. 
Schlagwein F. (2021), Hungary: 'Black Lives Matter' Sculpture Stirs Controversy | $D W \mid$ 12.01.2021, DW, accessed February 2021, https://www.dw.com/en/ hungary-black-lives-matter-R-stirs-controversy/a-56194846.

Shabi R. (2016), How Europe'S Far-Right Feasts on Trump'S Victory, Aljazeera, accessed February 2021, https:/www.aljazeera.com/opinions/2016/11/17/howeuropes-far-right-feasts-on-trumps-victory.

Tjalve V. S. (2020), The Return Of Machismo Geopolitics, DIIS, accessed February 2021.

Tondo L. (2019), 'Sardines'Against Salvini: Italy's Fight Against the Far-right, "The Guardian", https://www.theguardian.com/world/2019/dec/14/sardines-packpiazza-in-rome-for-protest-against-matteo-salvini.

Trevor J., Knight-Finley M. (2019), Immigration Policy and Left-Right Politics in Western Europe, The Palgrave Handbook of Ethnicity.

Vogel K. P., Scott S., Patrick K. (2018), How Vilification Of George Soros Moved From The Fringes To The Mainstream (Published 2018), "Nytimes", accessed February 2021, https:/www.nytimes.com/2018/10/31/us/politics/george-soros-bombs-trump.html.

Waterfield B. (2020), Donald Trump Is Our Ally In War On EU'Loopy Liberals', Says Viktor Orban, Thetimes.Co.Uk, accessed February 2021, https://www. thetimes.co.uk/article/hungary-s-leader-viktor-orban-backs-donald-trumpagainst-loopy-liberals-rwmf56mc 7 .

Wildangel R. (2018), No Alternative: What The Afd Wants for Europe, ECFR, accessed February 2021, https://ecfr.eu/article/commentary_no_alternative what_the_afd_wants_for_europe/.

Zalan E. (2021), Orbán hosts first major meeting on new right-wing alliance, "EUobserver", accessed February 2021, https://euobserver.com/democracy/151408.

\section{Trumpizm i Europejska skrajna prawica: Analiza wplywu Trumpizmu na AfD, Lega Nord i Fidesz po 2016 roku}

\section{Streszczenie}

Celem artykułu jest zbadanie relacji między Trumpizmem a skrajnie prawicowymi partiami politycznymi w Europie. Połączenie wspólnych rdzeni ideologicznych i konfrontacji z podobnymi „wrogami” doprowadziło do powstania niespotykanej dotąd relacji, w której Trump odgrywa rolę „międzynarodowego ojca chrzestnego" $\mathrm{i}$ inspiratora europejskiej skrajnej prawicy. W celu zbadania tej relacji praca skupia się na odniesieniach do aktywności Donalda Trumpa, jego polityki i wypowiedzi w latach 2016-2020 w dyskursie Alternative für Deutschland (AfD), Węgierskiej Partii Obywatelskiej (Fidesz) i Lega Nord (Lega). Analiza dyskursu trzech partii w zakresie bezpieczeństwa, imigracji, polityki zagranicznej i korupcji pokazuje, że partie te wykorzystały Trumpizm jako inspirację w trzech aspektach. Po pierwsze, użyły go do 
normalizacji wcześniej istniejących skrajnie prawicowych ideologii i praktyk w kontekście narodowym i europejskim. Po drugie, naśladowali dyskurs Trumpa i jego polityki do zwiększenia jego popularności i wsparcia własnych dążeń narodowościowych. Po trzecie, wykorzystali walkę i idee Trumpa do uzasadnienia narodowych metod, wierzeń, krytyk i celów politycznych. W związku z tym artykuł ma ustalić główne motywy do wykorzystania Trumpizmu przez europejską skrajną prawicę do ustanowienia podwalin dla przyszłych analiz krytycznych i lepszego zrozumienia tej niespotykanej relacji.

Słowa kluczowe: Trumpizm, europejska skrajna prawica, populizm, AfD, Fidesz, La Lega Nord 